\title{
Manure nutrient excretion by Jersey and Holstein cows
}

\author{
K. F. Knowlton, ${ }^{\star 1}$ V. A. Wilkerson,† D. P. Casper, $\ddagger$ and D. R. Mertens $\S$ \\ *Department of Dairy Science, Virginia Polytechnic Institute and State University, Blacksburg 24061 \\ †Land O'Lakes Purina Feed LLC, Portland, OR 97229 \\ †Agri-King, Fulton, IL 61252 \\ §US Dairy Forage Research Center, Madison, WI 53706
}

\section{ABSTRACT}

The objective of this study was to evaluate feces, urine, and $\mathrm{N}$ excretion by Jersey and Holstein cows. Sixteen multiparous cows ( $\mathrm{n}=8$ per breed) were fed 2 experimental rations at calving in a switchback experimental design. Diets were $50 \%$ forage and based on corn meal (control) or whole cottonseed. Half the cows in each breed started on the control diet and half started on the whole cottonseed diet. Cows were switched to the other diet at $60 \mathrm{~d}$ in milk and switched back to their original diet at $165 \mathrm{~d}$ in milk. Pairs of cows were moved into open-circuit respiration chambers on d 49, 154, and 271 of lactation for 7-d measurement periods. While in the chambers, total collection of feed refusals, milk, recovered hair, feces, and urine was conducted. No effect of the interaction of diet and breed was observed for measures of nutrient digestibility and manure excretion. Total daily manure excretion was lower in Jersey cows than in Holstein cows, with reductions generally proportional to changes in feed intake. Jersey cows consumed $29 \%$ less feed and excreted $33 \%$ less wet feces and $28 \%$ less urine than Holstein cows. Intake, fecal, and urinary $\mathrm{N}$ were reduced by 29,33 , and $24 \%$, respectively, in Jersey cows compared with Holstein cows. Equations from American Society of Agricultural and Biological Engineers underpredicted observed values for all manure measures evaluated (urine, manure solids, N, wet manure), and breed bias was observed in equations predicting excretion of urine, $\mathrm{N}$, and wet manure. Although these equations include animal and dietary factors, intercepts of regression of observed values on predicted values differed between Holsteins and Jerseys for those 3 measures. No breed bias was observed in the prediction of manure solids excretion, however, making that equation equally appropriate for Jerseys and Holsteins. The effect of breed on manure and nutrient excretion has significant nutrient management implications.

Received August 5, 2009.

Accepted September 21, 2009.

${ }^{1}$ Corresponding author: knowlton@vt.edu
Key words: urine nitrogen, storage, dietary protein, heifer

\section{INTRODUCTION}

With the changes in the definition of concentrated animal feeding operations (CAFO) and the inclusion of smaller farms, nutrient management planning is a priority for livestock producers (EPA, 2002). An abundance of information is available on manure nutrient excretion from lactating Holstein cows (Wilkerson et al., 1997; St-Pierre and Threan, 1999; Knowlton et al., 2001; Haig et al., 2002; Davidson et al., 2003), but data quantifying nutrient excretion by Jersey cows are scarce. When the estimates for manure and nutrient excretion by dairy cows were updated by the American Society of Agricultural and Biological Engineers (ASAE; ASAE, 2005), only Holstein data were used to derive equations to predict manure and nutrient excretion (Nennich et al., 2005, 2006).

Limited data suggest that differences in manure and nutrient excretion of Jersey and Holstein cows may be large enough to merit consideration in nutrient management planning and CAFO permitting. One study conducted in the late 1970s (Blake et al., 1986) reported that Jersey cows excreted about $70 \%$ of the fecal $\mathrm{N}$ and $90 \%$ of the urinary N of Holstein cows (Jerseys had $70 \%$ of the BW and $79 \%$ of the DMI of Holsteins). Similarly, Kauffman and St-Pierre (2001) found that Jersey cows excreted $71 \%$ of the feces and $73 \%$ of the $\mathrm{N}$ excreted by Holstein cows. In both of these studies, the authors concluded that differences in feces and $\mathrm{N}$ excretion were caused by differences in BW and DMI rather than by any difference in digestibility or postabsorptive nutrient utilization. In neither study was data on excretion of urine or wet feces reported.

Additional data on manure and nutrient excretion by Jersey cows is needed to support appropriate nutrient management planning on Jersey dairy farms. Nutrient excretion data from a large multi-objective study were evaluated to address this issue. The study was conducted at the former Energy Metabolism Unit in the Animal and Natural Resources Institute (then 
Table 1. Ingredient composition of rations fed to lactating Jersey and Holstein cows

\begin{tabular}{lcc}
\hline Ingredient, \% of diet DM & Whole cottonseed & Control \\
\hline Alfalfa silage & 30.0 & 30.0 \\
Corn silage & 20.0 & 20.0 \\
Corn meal & 28.5 & 32.1 \\
Whole cottonseed & 10.0 & - \\
Cottonseed meal & - & 4.09 \\
Cottonseed hulls & 8.29 & 2.30 \\
Soybean meal & 0.80 & 8.29 \\
Fish meal & 0.80 & 0.80 \\
Blood meal & 0.86 & 0.80 \\
Dicalcium phosphate & 0.50 & 0.86 \\
Trace mineralized salt + selenium & 0.05 & 0.50 \\
Magnesium oxide & 0.09 & 0.05 \\
Sulfur & 0.004 & 0.09 \\
Zinc oxide & 0.04 & 0.004 \\
Vitamin A & 0.04 \\
Vitamin D & 0.02 & 0.02 \\
Vitamin $\mathrm{E}^{3}$ & 0.05 & 0.05 \\
\hline
\end{tabular}

${ }^{1}$ Contained 10,000 KIU of vitamin A per kg.

${ }^{2}$ Contained $3,000 \mathrm{KIU}$ of vitamin D per $\mathrm{kg}$.

${ }^{3}$ Contained 44,000 IU of vitamin E per kg.

Livestock and Poultry Sciences Institute) at Beltsville, Maryland. The objectives of the larger study were 1) to compare energy utilization by multiparous Jersey and Holstein cows, 2) to determine the energy value of whole cottonseed in rations, 3) to evaluate the effects of diets varying in energy density on milk and blood lipids in Jersey and Holstein cows, and 4) to evaluate manure and nutrient excretion by Jersey and Holstein cows. The results of the first 2 aspects of the larger study were in Tyrrell et al. (1991) and the milk and blood lipid data were presented in Bitman et al. (1996). This report presents effects of breed on feces, urine, and $\mathrm{N}$ excretion.

\section{MATERIALS AND METHODS}

\section{Animals and Diets}

Details of the experimental design, treatments, sample collection, and analysis are in Bitman et al. (1996). Briefly, multiparous Jersey $(\mathrm{n}=8)$ and Holstein $(\mathrm{n}=$ 8) cows were paired by calving date, lactation number, and health history and were fed 2 experimental rations at calving in a switchback experimental design. Diets were $50 \%$ forage and based on corn meal (control) or whole cottonseed (Table 1). Half the cows in each breed started on the control diet and half started on the whole cottonseed diet. Cows were switched to the opposite diet at 60 DIM and switched back to their original diet at 165 DIM. Cows were housed in a climate-controlled barn $\left(17 \mathrm{~h}\right.$ of light, $7 \mathrm{~h}$ of darkness, $16^{\circ} \mathrm{C}$, and $60 \%$ relative humidity) and removed twice daily for milking (0600 and $1800 \mathrm{~h}$ ). Cows were allowed exercise in outdoor paved lots for 2 to $4 \mathrm{~h} / \mathrm{d}$; breeds were kept separate during exercise.

\section{Sample Collection and Analysis}

Pairs of cows were moved into open-circuit respiration chambers on d 49, 154, and 271 of lactation for 7-d measurement periods. While in the chambers, total collection of feed refusals, milk, recovered hair, feces, and urine was conducted. Cows were fitted with a urinary catheter (24 French, 75 mL; C. R. Bard Inc., Covington, GA) and immediately moved to the respiration chambers for a 48-h adaptation to both the respiration chamber and the catheter. Urine was collected in sealed, clean, preacidified ( $400 \mathrm{~mL}$ of $30 \%$ phosphoric acid) containers.

Feces and urine were weighed and a daily composite sample was frozen, then temporarily thawed, mixed thoroughly, and subsampled for total Kjeldahl N analysis. Frozen feces, feed, and orts samples were coarsely chopped and then ground with dry ice and analyzed for $\mathrm{DM}$, ash, total Kjeldahl N, ether extract, NDF, ADF, and lignin (Table 2). Milk samples were collected at each milking of the 7-d measurement period, preserved with potassium dichromate, frozen and then later thawed, composited by milk weight, and analyzed for protein.

\section{Statistical Analysis}

All data were analyzed using the MIXED procedure of SAS (2003) with the model

$$
\mathrm{Y}_{\mathrm{ijk}}=\mu+\mathrm{D}_{\mathrm{i}}+\mathrm{B}_{\mathrm{j}}+\mathrm{DB}_{\mathrm{ij}}+\mathrm{T}_{\mathrm{k}}+\mathrm{BT}_{\mathrm{jk}}+\mathrm{E}_{\mathrm{ijk}},
$$

where $Y_{\mathrm{ijk}}$ is the observed value; $\mu$ is the overall population mean; $\mathrm{D}_{\mathrm{i}}$ is the effect of ith dietary treatment $(\mathrm{i}=$ $1,2) ; B_{j}$ is the effect of $\mathrm{jth}$ breed $(\mathrm{j}=1,2) ; \mathrm{DB}_{\mathrm{ij}}$ is the interaction of dietary treatment and breed; $\mathrm{T}_{\mathrm{k}}$ is the effect of the kth trial $(\mathrm{k}=1,2,3)$; $\mathrm{BT}_{\mathrm{jk}}$ is the interaction of breed and trial; and $\mathrm{E}_{\mathrm{ijk}}$ is the residual error term. Results were reported as least squares means and differences were declared significant at $P<0.05$.

Table 2. Nutrient composition of rations fed to lactating Jersey and Holstein cows

\begin{tabular}{lcc}
\hline Item & Whole cottonseed & Control \\
\hline $\mathrm{DM}, \%$ & 52.1 & 52.7 \\
$\mathrm{CP}, \%$ of diet DM & 17.7 & 17.7 \\
$\mathrm{NDF}, \%$ of diet DM & 44.0 & 40.0 \\
$\mathrm{ADF}, \%$ of diet DM & 25.5 & 24.9 \\
$\mathrm{NE}_{\mathrm{L}}$, Mcal $/ \mathrm{kg}$ & 1.69 & 1.63 \\
Ether extract, \% of diet DM & 4.90 & 2.94 \\
Ash, \% of diet DM & 7.0 & 7.0 \\
\hline
\end{tabular}


Equations from the ASAE Manure Production and Characteristics Standards (ASAE, 2005) were used to compare the data from this study to predicted values. Individual cow observations from each trial from the current data set were used for regression analysis of observed and predicted values for equations for urine, total wet manure, total manure $\mathrm{N}$, and total manure solids excretion. Regression equations were derived by breed and PROC REG (SAS Institute, 2003) was used to determine whether the slopes of the equations were different from 1.0 or were affected by breed. When slopes were not affected by breed, pooled slope intercept equations were derived to compare individual intercepts for the 2 breeds.

The following equations from Section 5.0 Equations for As-Excreted Manure Characteristics for Dairy Cattle (ASAE, 2005) were evaluated. Equation numbers refer to those used in the ASAE publication.

\section{Total Manure $\left(M_{E}\right)$}

$$
\begin{aligned}
& \mathrm{M}_{\mathrm{E}}=(\text { milk } \times 0.172)+(\mathrm{DMI} \times 2.207) \\
&+(\mathrm{MF} \times 171.830)+(\mathrm{MTP} \times 505.310)-8.170[1] \\
& \mathrm{M}_{\mathrm{E}}=(\mathrm{milk} \times 0.954)+(\mathrm{BW} \times 0.037) \\
&+(\mathrm{DIM} \times 0.017)+(\mathrm{MF} \times 186.720) \\
& \quad+(\mathrm{MTP} \times 1,141.480)-33.06 \\
& \mathrm{M}_{\mathrm{E}}=(\mathrm{milk} \times 0.647)+43.212
\end{aligned}
$$

\section{Total Solids (DM $M_{E}$}

$$
\begin{gathered}
\mathrm{DM}_{\mathrm{E}}=(\mathrm{DMI} \times 0.350)+1.017 \\
\mathrm{DM}_{\mathrm{E}}=(\text { milk } \times 0.135)+(\mathrm{BW} \times 0.004) \\
+(\mathrm{DIM} \times 0.004)+(\mathrm{MTP} \times 118.370)-2.456 \\
\mathrm{DM}_{\mathrm{E}}=(\text { milk } \times 0.096)+5.073
\end{gathered}
$$

\section{Urine Volume $\left(U_{E}\right)$}

$$
\begin{gathered}
\mathrm{UE}=(\text { milk } \times 0.114)+(\mathrm{BW} \times 0.016) \\
+(\mathrm{MF} \times 97.709)+(\mathrm{MTP} \times 353.28) \\
+\left(\mathrm{C}_{\mathrm{CP}} \times 62.036\right)-16.389 \\
\mathrm{U}_{\mathrm{E}}=(\mathrm{BW} \times 0.017)+11.704
\end{gathered}
$$

\section{$N$ Excretion $\left(N_{E}\right)$}

$$
\begin{gathered}
\mathrm{N}_{\mathrm{E}}=(\mathrm{milk} \times 2.303)+(\mathrm{DIM} \times 0.159)+(\mathrm{DMI} \\
\left.\times \mathrm{C}_{\mathrm{CP}} \times 70.138\right)+(\mathrm{BW} \times 0.193)-56.632 \\
\mathrm{~N}_{\mathrm{E}}=(\operatorname{milk} \times 5.959)+(\mathrm{DIM} \times 0.237) \\
+(\mathrm{BW} \times 0.347)+(\mathrm{MTP} \times 4,547.910) \\
\quad+\left(\mathrm{C}_{\mathrm{CP}} \times 1,793.730\right)-476.530 \\
\mathrm{~N}_{\mathrm{E}}=(\text { milk } \times 4.204)+283.300
\end{gathered}
$$

In these equations, milk = milk yield, kilograms per day; $\mathrm{BW}=$ body weight, kilograms; DMI = dry matter intake, kilograms per day; $\mathrm{MF}=$ milk fat yield, grams per grams of milk per day; MTP = milk true protein, grams per grams of milk per day; and $\mathrm{C}_{\mathrm{CP}}=$ dietary concentration of CP.

\section{RESULTS AND DISCUSSION}

\section{Production Performance}

There were no effects of the interaction of breed and diet on any measure of manure and nutrient excretion; this discussion will focus on main effects of breed. As expected, Jersey cows consumed less DM ( $71 \%$ of that consumed by Holstein cows; Table 3) and less water (63\% of Holstein cows) and produced less milk (62\% of that produced by Holstein cows). Jersey cows were smaller than Holstein cows (426 vs. $629 \mathrm{~kg}$, respectively) and DMI per unit of BW was not significantly different (3.90 and $3.55 \%$ for Jerseys and Holsteins respectively; $P<0.16)$.

[7] Although not significantly affected by breed, the observed values for DMI per unit of BW were similar to those previously reported for Holstein and Jersey cows (Blake et al., 1986; West et al., 1990; Rastani et al., 2001). Grainger and Goddard (2004) reviewed 10 publications from the United States, Europe, and New Zealand and reported that Jerseys consumed more feed per unit of BW than Holsteins by margins of +4.3 to $+23.5 \%$. The effect of breed was greater in the United States and Europe because of the larger difference in body sizes in those countries than in New Zealand and because of the ad libitum feeding practices in the former. In a recent field trial (Anderson et al., 2007), Jerseys and Jersey $\times$ Holstein crosses (a mixed pen with $30 \%$ purebred Jerseys) consumed $8 \%$ more feed per unit of BW than Holstein cows (4.26 vs. $3.96 \%$ of BW, respectively). In cows fed a grass silage-based 
Table 3. Feed intake, BW, milk production, and manure excretion by lactating Jersey and Holstein cows

\begin{tabular}{lcccc}
\hline Item & Holstein & Jersey & SEM & Effect of breed $(P<)$ \\
\hline Cows, n & 8 & 8 & & \\
DMI, kg/d & 22.4 & 15.8 & 0.77 & 0.01 \\
Water intake, ${ }^{1} \mathrm{~kg} / \mathrm{d}$ & 89.0 & 56.1 & 3.75 & 0.01 \\
Milk yield, kg/d & 33.9 & 21.1 & 1.97 & 0.01 \\
BW, kg & 629 & 426 & 24.8 & 0.01 \\
DMI, \% of BW & 3.55 & 3.90 & 0.17 & 0.16 \\
Wet feces excretion, kg/d & 51.7 & 33.6 & 2.22 & 0.01 \\
Feces, \% DM & 15.8 & 16.9 & 0.26 & 0.01 \\
Feces DM, kg/d & 8.11 & 5.67 & 0.32 & 0.01 \\
DM digestibility, \% & 63.9 & 64.8 & 0.43 & 0.19 \\
Urine excretion, $\mathrm{kg} / \mathrm{d}$ & 22.7 & 16.3 & 0.85 & 0.01 \\
Total wet manure excretion, ${ }^{2} \mathrm{~kg} / \mathrm{d}$ & 74.3 & 49.8 & 2.34 & 0.01 \\
Total daily wet manure excretion, g/kg of BW & 118 & 123 & 5.27 & 0.57 \\
\hline
\end{tabular}

${ }^{1}$ Free water intake, not including moisture in ration.

${ }^{2}$ Wet feces plus urine, no bedding.

diet, however, Aikman et al. (2008) reported no effect of breed on feed intake per unit of BW (mean $=3.48 \%$ of BW).

\section{Manure Excretion}

Manure excretion was lower in Jersey cows than in Holstein cows, with reductions generally proportional to changes in feed intake (Table 3). Jersey cows excreted $35 \%$ less wet feces and 28\% less urine than Holstein cows. Fecal DM excretion was lower in Jersey cows than in Holstein cows, but DM digestibility and total wet manure production per unit of BW were unaffected by breed (Table 3). Feces from Jerseys was significantly drier than feces of Holsteins, but the magnitude of the difference was small (16.9 vs. $15.8 \%$, respectively; $P<$ 0.01 )

Others have observed few differences in digestive capacity between Jerseys and Holsteins after data are corrected for BW. Kauffman and St-Pierre (2001) found that Jersey cows excreted $71 \%$ as much feces as Holstein cows, but differences were caused by differences in BW and DMI rather than by any difference in digestibility or postabsorptive nutrient utilization. Likewise, no differences in feed efficiency were observed between Jersey $\times$ Holstein crossbred cows and Holstein cows (Heins et al., 2008) or between purebred Jerseys and Holsteins (Blake et al., 1986). Both Blake et al. (1986) and Aikman et al. (2008) reported similar DM digestibility in Jerseys and Holsteins, and Smith and Baldwin (1974) reported that organ weights were similar between the breeds when expressed on a common BW basis.

Excretion of $\mathrm{N}$ was lower in Jersey cows than in Holstein cows (Table 4), primarily because of lower $\mathrm{N}$ intake. Intake, fecal, and urinary $\mathrm{N}$ were reduced by 29 , 33 , and $24 \%$, respectively, in Jersey cows compared with Holstein cows. Reductions in fecal $\mathrm{N}$ were similar to the $30 \%$ reduction observed by Blake et al. (1986) and the $27 \%$ reduction reported by Kauffman and St-Pierre (2001), but the reduction in urinary $\mathrm{N}$ was greater than the $10 \%$ reduction observed by Blake et al. (1986). As in the study of Aikman et al. (2008), apparent N digestibility and total $\mathrm{N}$ excretion as a proportion of $\mathrm{N}$ intake were unaffected by breed. Total manure $\mathrm{N}$ excretion averaged $323 \mathrm{~g} / \mathrm{d}$ for these Jersey cows compared with $456 \mathrm{~g} / \mathrm{d}$ for Holstein cows. Milk N secretion was lower in the Jersey cows than in the Holstein cows, but was similar as a proportion of $\mathrm{N}$ intake $(25.4 \pm 0.83 \% ; P<$ $0.86)$. Nitrogen balance (retention) was unaffected by breed.

Table 4. Nitrogen intake and excretion by lactating Jersey and Holstein cows

\begin{tabular}{lcccc}
\hline Item & Holstein & Jersey & SEM & Effect of breed $(P<)$ \\
\hline N intake, g/d & 631 & 447 & 21.9 & 0.01 \\
Fecal N excretion, g/d & 243 & 162 & 10.2 & 0.01 \\
Apparent N digestibility, \% & 61.9 & 63.9 & 0.58 & 0.03 \\
Urinary N excretion, g/d & 213 & 161 & 6.3 & 0.01 \\
Urinary N, \% of N intake & 34.4 & 36.6 & 1.14 & 0.19 \\
Milk N, g/d & 162 & 115 & 7.98 & 0.01 \\
Milk N, \% of N intake & 25.3 & 25.5 & 0.83 & 0.86 \\
N balance, g/d & 13.9 & 8.9 & 0.38 & 0.36 \\
Total manure N excretion, g/d & 456 & 323 & 14.1 & 0.01 \\
Total manure N excretion, \% of N intake & 72.6 & 72.7 & 0.86 & 0.90 \\
\hline
\end{tabular}


Table 5. Relationship between observed $(\mathrm{Y})$ and $\operatorname{predicted}^{1}(\mathrm{X})$ manure excretion in lactating Jersey $(\mathrm{J})$ and Holstein $(\mathrm{H})$ cows

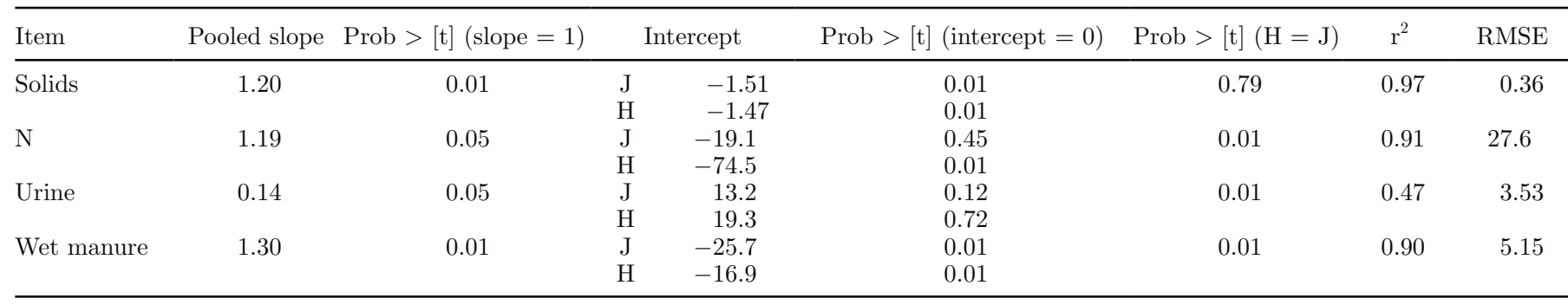

${ }^{1}$ ASAE (2005) section 5.3 lactating cow regression equations: Wet manure excretion, $\mathrm{kg} / \mathrm{d}=(\mathrm{milk} \times 0.172)+(\mathrm{DMI} \times 2.207)+(\mathrm{MF} \times 171.830)$ $+(\mathrm{MTP} \times 505.310)-8.170$. Manure solids excretion, $\mathrm{kg} / \mathrm{d}=(\mathrm{DMI} \times 0.350)+1.017$ (assumes urine solids content of $4.5 \%)$. Urine excretion, $\mathrm{kg} / \mathrm{d}=(\operatorname{milk} \times 0.114)+(\mathrm{BW} \times 0.016)+(\mathrm{MF} \times 97.709)+(\mathrm{MTP} \times 353.280)+\left(\mathrm{C}_{\mathrm{CP}} \times 62.036\right)-16.389 . \mathrm{Manure} \mathrm{N}$ excretion, $\mathrm{g} / \mathrm{d}=($ milk $\times$ $2.303)+(\mathrm{DIM} \times 0.159)+\left(\mathrm{DMI} \times \mathrm{C}_{\mathrm{CP}} \times 70.138\right)+(\mathrm{BW} \times 0.193)-56.632$. Milk $=$ milk yield, $\mathrm{kg} / \mathrm{d} ; \mathrm{BW}=$ body weight, $\mathrm{kg} ; \mathrm{DMI}=$ dry matter intake, $\mathrm{kg} / \mathrm{d} ; \mathrm{MF}=$ milk fat yield, $\mathrm{g} / \mathrm{g}$ of milk per day; $\mathrm{MTP}=$ milk true protein, $\mathrm{g} / \mathrm{g}$ of milk per day; $\mathrm{C}_{\mathrm{CP}}=$ dietary concentration of $\mathrm{CP}$.

The effect of breed on manure and nutrient excretion has significant nutrient management implications. The revised federal CAFO regulations (and the CAFO permitting programs of many states) define CAFO by a specified number of cows, making no distinction among breeds or cow size. The $33 \%$ reduction in total wet manure and $29 \%$ reduction in total $\mathrm{N}$ excretion reported here is similar to reductions observed by others (Blake et al., 1986; Kauffman and St-Pierre, 2001) and substantial enough to warrant consideration in nutrient management planning.

\section{Application of ASAE Prediction Equations to Jerseys}

This data set and the observations of Kauffman and St-Pierre (2001) suggest that the reduced feces and urine excretion by Jersey cows is primarily caused by breed differences in DMI and BW rather than by any inherent differences in DM digestion or postabsorptive metabolism. Therefore, although the tabular values for daily manure excretion derived from Holstein cows (ASAE, 2005) are clearly not appropriate for Jersey cows, evaluation of the applicability of prediction equations (based on animal and dietary factors) to Jerseys is merited.

The ASAE equations not based on nutrient intake (equations 2, 3, 8, 9, 13, 15, and 16) fit the observed data with far less precision than the equations based on nutrient intake (equations 1, 7, 12, and 14; Table 5). Coefficients of determination were lower for equations not based on nutrient intake (2 equations used for each nutrient) compared with equations based on nutrient intake in prediction of solids $\left(\mathrm{r}^{2}=0.59\right.$ and 0.80 vs. $0.97), \mathrm{N}\left(\mathrm{r}^{2}=0.70\right.$ and 0.84 vs. 0.91$)$, and wet manure $\left(\mathrm{r}^{2}=0.61\right.$ and 0.79 vs. 0.90$)$ excretion. Equations predicting urine were equally $(\mathrm{im})$ precise $\left(\mathrm{r}^{2}=0.47\right)$. The equations based on nutrient intake were reported in the ASAE publication to have lower residual error, and the authors recommended that "equations with the lowest residual error should be used whenever input variables are available" (ASAE, 2005). The remainder of this discussion focuses on the results of evaluation of the more precise equations (equations $1,7,12$, and 14 ; ASAE, 2005).

Observed values for manure solids, manure $\mathrm{N}$, and wet manure were greater than ASAE predicted (slopes $\neq 1$; Table 5) but there was no effect of breed on slopes of these regressions (linear bias similar for the 2 breeds). For manure solids, there was no effect of breed on the intercepts of regression lines. The lack of breed bias in the prediction of manure solids excretion by ASAE makes that equation equally applicable to the 2 breeds.

Observed $\mathrm{N}$ excretion was not predicted accurately by the ASAE (2005) equation. The coefficient of determination was high $\left(\mathrm{r}^{2}>0.91\right.$, pooled slope analysis), but breed differences in the intercept were observed $(P<0.01)$. The Jersey intercept $(-19.1)$ was not different from zero; the Holstein intercept $(-74.5)$ was significantly different from the Jersey intercept. The biological explanation for the breed difference is not apparent, but high error (both interstudy and residual) was associated with the $\mathrm{N}$ equation (Nennich et al., 2005).

Predicted values for urine excretion did not fit the observed data well for either breed. Slopes were not different from zero, indicating no relationship between observed and predicted urine. This is likely because of variation in intake of minerals $(\mathrm{Na}, \mathrm{K})$ not included in the prediction equation. The relationship between predicted and observed wet manure excretion was strong $\left(\mathrm{r}^{2}=0.90\right.$, slope $\left.=1.30\right)$ and not affected by breed, but the intercept of the regression lines was lower for Jerseys than for Holsteins ( -25.7 vs. -16.9 , respectively; $P<0.01)$.

\section{CONCLUSIONS}

Excretion of wet feces, urine, manure solids, and $\mathrm{N}$ by lactating Jersey cows is lower than Holstein cows, 
proportional to differences in DMI and BW. The ASAE tabular values for daily manure excretion derived from Holstein cows are not appropriate for Jersey cows, and breed bias was evident in equations predicting excretion of $\mathrm{N}$, urine, and wet manure. However, manure solids prediction equations are equally appropriate for Jersey and Holstein cows. Differences between breeds are large enough to merit consideration in nutrient management planning and CAFO permitting. Accounting for breed differences in manure excretion will support more effective nutrient management planning on dairy farms.

\section{ACKNOWLEDGMENTS}

Funds for this research were provided by the American Jersey Cattle Club Research Foundation (Reynoldsburg, $\mathrm{OH})$. The indirect respiration calorimetry experiment was conducted at the former Energy Metabolism Unit within the USDA-ARS facility at Beltsville, Maryland. The authors appreciate assistance with statistical analysis provided by Ranga Appuhamy (Department of Dairy Science, Virginia Tech, Blacksburg).

\section{REFERENCES}

Aikman, P. C., C. K. Reynolds, and D. E. Beever. 2008. Diet digestibility, rate of passage, and eating and rumination behavior of Jersey and Holstein cows. J. Dairy Sci. 91:1103-1114.

ASAE. 2005. Manure production and characteristics. ASAE stands D384.2. American Society of Agricultural and Biological Engineers, St. Joseph, MI.

Anderson, T., R. Shaver, P. Bosma, and V. De Boer. 2007. Case study: Performance of lactating Jersey and Jersey-Holstein crossbred versus Holstein cows in a Wisconsin confinement dairy herd. Prof. Anim. Sci. 23:541-545.

Bitman, J., D. L. Wood, R. H. Miller, H. F. Tyrrell, C. K. Reynolds, and H. D. Baxter. 1996. Comparison of milk and blood lipids in Jersey and Holstein cows fed total mixed rations with or without whole cottonseed. J. Dairy Sci. 79:1596-1602.

Blake, R. W., A. A. Custodio, and W. H. Howard. 1986. Comparative feed efficiency of Holstein and Jersey cows. J. Dairy Sci. 69:13021308.

Davidson, S., B. A. Hopkins, D. E. Diaz, S. M. Bolt, C. Brownie, V. Fellner, and L. W. Whitlow. 2003. Effects of amounts and degradability of dietary protein on lactation, nitrogen utilization, and excretion in early lactation Holstein cows. J. Dairy Sci. $86: 1681-1689$.
EPA. 2002. Concentrated animal feeding operations clean water act requirements: What are the federal requirements for dairy cow and heifer CAFOs? 833-F-02-009. United States Environmental Protection Agency, Washington, DC.

Grainger, C., and M. E. Goddard. 2004. A review of the effects of dairy breed on feed conversion efficiency-An opportunity lost? Pages 77-80 in Proceedings of the 25th Biennial Conference of the Australian Society of Animal Production. Australian Society of Animal Production, Park Ridge, Australia.

Haig, P. A., T. Mutsvangwa, R. Spratt, and B. W. McBride. 2002. Effects of dietary protein solubility on nitrogen losses from lactating dairy cows and comparison with predictions from the Cornell Net Carbohydrate and Protein System. J. Dairy Sci. 85:1208-1217.

Heins, B. J., L. B. Hansen, A. J. Seykora, A. R. Hazel, D. G. Johnson, and J. G. Linn. 2008. Crossbreds of Jersey $\times$ Holstein compared with pure Holsteins for body weight, body condition score, dry matter intake, and feed efficiency during the first one hundred fifty days of first lactation. J. Dairy Sci. 91:3716-3722.

SAS Institute. 2003. SAS Users Guide. Version 9.1. SAS Institute, Cary, NC.

Kauffman, A. J., and N. R. St-Pierre. 2001. The relationship of milk urea nitrogen to urine nitrogen excretion in Holstein and Jersey cows. J. Dairy Sci. 84:2284-2294.

Knowlton, K. F., J. H. Herbein, M. A. Meister-Weisbarth, and W. A. Wark. 2001. Nitrogen and phosphorus partitioning in lactating Holstein cows fed different sources of dietary protein and phosphorus. J. Dairy Sci. 84:1210-1217.

Nennich, T. D., J. H. Harrison, L. M. VanWieringen, D. Meyer, A. J. Heinrichs, W. P. Weiss, N. R. St-Pierre, R. L. Kincaid, D. L. Davidson, and E. Block. 2005. Prediction of manure and nutrient excretion from dairy cattle. J. Dairy Sci. 88:3721-3733.

Nennich, T. D., J. H. Harrison, L. M. VanWieringen, N. R. St-Pierre, R. L. Kincaid, M. A. Wattiaux, D. L. Davidson, and E. Block. 2006. Prediction and evaluation of urine and urinary nitrogen and mineral excretion from dairy cattle. J. Dairy Sci. 89:353-364.

Rastani, R. R., S. M. Andrew, S. A. Zinn, and C. J. Sniffen. 2001 Body composition and estimated tissue energy balance in Jersey and Holstein cows during early lactation. J. Dairy Sci. 84:12011209 .

Smith, N., and R. L. Baldwin. 1974. Effects of breed, pregnancy, and lactation on weight of organs and tissues in dairy cattle. J. Dairy Sci. 57:1055-1060.

St-Pierre, N. R., and C. S. Threan. 1999. Animal grouping strategies, sources of variation, and economic factors affecting nutrient balance on dairy farms. J. Dairy Sci. 82(Suppl. 2):72-83.

Tyrrell, H. F., C. K. Reynolds, and H. D. Baxter. 1991. Effect of dietary fat from whole cottonseed on energy metabolism of lactating Holstein and Jersey cows. J. Dairy Sci. 74(Suppl. 1):250.

West, J. W., K. Bondari, and J. C. Johnson Jr.. 1990. Effects of bovine somatotropin on milk yield and composition, body weight, and condition score of Holstein and Jersey cows. J. Dairy Sci. 73:1062-1068.

Wilkerson, V. A., D. R. Mertens, and D. P. Casper. 1997. Prediction of excretion of manure nitrogen by Holstein dairy cattle. J. Dairy Sci. 80:3193-3204. 